\title{
Bioactive compounds, health benefits and utilization of Rhododendron: a comprehensive review
}

\author{
Vikas Kumar ${ }^{*}(\mathbb{0}$, Sheenam Suri, Rasane Prasad, Yogesh Gat, Chesi Sangma, Heena Jakhu and Manjri Sharma
}

\begin{abstract}
The Rhododendron distributed throughout the world is a small evergreen tree with deep red or pale pink flowers, belongs to the family Ericaceae and is known for its spectacular flowers. The species is widely distributed between the latitudes $80^{\circ} \mathrm{N}$ and $20^{\circ} \mathrm{S}$ with high socioeconomic reverence and has been designated as the national flower of Nepal and state flower of Himachal Pradesh (India). In addition to its immense horticultural importance, it is commonly used as an ornamental plant for gardens, plantations in the streets or vessels for its aesthetic value. Because of its numerous phytochemical potential, it is being utilized as a traditional remedy for different diseases. Flowers of this plant are traditionally utilized by the people residing in the mountainous region to make pickle, juice, jam, syrup, honey, squash, etc., and to treat various ailments like diarrhea, headache, inflammation, bacterial and fungal infections. The present review highlights the medicinal, nutritional and potential properties of Rhododendron by making value-added products to improve the livelihood for sustainable development of the rural tribal population with more job opportunities.
\end{abstract}

Keywords: Rhododendron, Ericaceae, Ornamental, Inflammation, Nutritive value

\section{Background}

Nature provides us an access to a diverse group of plants with numerous usages including decoration, medicinal, flowering and fruiting. Nowadays, the cultivation of plants for medicinal as well as commercial purposes is of extreme antiquity, and the researchers are exploring the underutilized plants which are being utilized for different purposes traditionally. India is known for its vast biological diversity and rich traditional systems of medicine (Ayurveda), which forms a strong base for the exploration of various plants for general health care. Rhododendron is one such plant that is acquiring a special place in the cultural as well as economic life of the people. Rhododendron is derived from Greek word: "rhodo" means "rose" and "dendron" means "tree." It belongs to the family, Ericaceae, and was first described by Carl Linnaeus in 1837 [1]. Rhododendron was originated in the valley of Himalayas, Kashmir, Assam, Manipur in India and

*Correspondence: vkchoprafst@rediffmail.com

Food Technology and Nutrition, School of Agriculture, Lovely Professional University, Phagwara, Punjab 144411, India in some regions of Bhutan. The aesthetic beauty of the fully blossomed flowers in the flowering season attracts the attention of the visitors [2]. Due to these reasons, the flower has been entitled as the national flower of Nepal and state flower of Himachal Pradesh (India).

India has been considered as a treasure house of medicinal and aromatic plant species. According to WHO (2000), $65 \%$ of the world's population integrate the medicinal plant for treatment and $80 \%$ of the Indian population used plant product for treating many diseases [3]. Rhododendron is one of the naturally occurring plants which possess various health benefits, such as prevention and treatment of diseases associated with heart, dysentery, diarrhea, detoxification, inflammation, fever, constipation, bronchitis and asthma [4]. The leaves possess effective antioxidant activity. The young leaves are used to alleviate headache. The wood of this plant can be used for making khukri handles, packsaddles, gift boxes, gunstocks and posts [5]. Due to the limited availability of the flower, researchers and processors in food and pharmaceutical sectors, with few exceptions, did not yet exploit it. This review focuses on the classification, locality, area 
and production, composition, distribution, medicinal properties, utilization and future prospective of the Rhododendron with the aim of dispersing the facts related to it.

\section{Classification and distribution}

Taxonomists have made different classifications based on morphological data, i.e., flowers, leaves, hair, etc., due to different species of its kind. Rhododendron, the largest genus of the Ericaceae family, includes 1200 species which is distributed throughout the Northeast Asia and Eurasia, Western Europe and North America [6]. Approximately, more than $70 \%$ of 500 Rhododendron species are endemic in China. Rhododendron species, $R$. protistum var. giganteum, was first named and identified by George Forrest in 1919, which is one of the tallest and most ancient Rhododendron trees [7], therefore honored as the "King of Rhododendron" [8]. Among all the Rhododendron species, Rhododendron arboreum is widely distributed, and most commonly found subspecies of the same are presented in Table 1 [2].

Rhododendron, a most famous horticulture plant, has become one of the most popular plants in the gardens and as avenue trees [9] and has also been widely cultivated in different parts of the world due to its ethnical uses, commercial and medicinal values. It covers a vast section of Southeastern Asia between the Northwestern Himalaya through Nepal, Sikkim, Eastern Tibet, Bhutan, Arunachal Pradesh, and Upper Burma, Western and Central China. All these places account for more than 90\% of the world's natural population of Rhododendrons.

\section{Composition of Rhododendron arboreum}

Rhododendron contains minerals such as manganese, iron, zinc, copper, sodium, chromium, cobalt, cadmium, molybdenum, nickel, lead and arsenic. Minerals play a vital role in maintaining certain physicochemical processes which are essential for life. Manganese, copper, selenium, zinc, iron and molybdenum are important

Table 1 Subspecies of Rhododendron arboreum

\begin{tabular}{lc}
\hline Subspecies & Characteristics and distribution \\
\hline $\begin{array}{l}\text { Rhododendron arboreum spp. } \\
\text { Arboreum }\end{array}$ & $\begin{array}{c}\text { Red flower, found in Western } \\
\text { Himalayas }\end{array}$ \\
$\begin{array}{l}\text { Rhododendron arboreum spp. Cin- } \\
\text { namomeum }\end{array}$ & $\begin{array}{c}\text { White, pink or red flower, found in } \\
\text { Central Himachal }\end{array}$ \\
$\begin{array}{l}\text { Rhododendron arboreum spp. } \\
\text { Delavayii }\end{array}$ & $\begin{array}{c}\text { Red flower, found in Eastern } \\
\text { Himalayas }\end{array}$ \\
$\begin{array}{l}\text { Rhododendron arboreum spp. } \\
\text { Nilagiricum }\end{array}$ & Red flowers, found in Nilgiri \\
Rhododendron arboreum spp. & Orange red flowers, found in Sri \\
Zeylancium & Lanka \\
\hline
\end{tabular}

cofactors found in the structure of certain enzymes and are indispensable in numerous biochemical pathways. Sodium is important in maintaining the osmotic balance between cells and interstitial fluid [10]. A brief composition of the Rhododendron flower is given in Table 2.

Table 3 depicts the phytochemical potential of different parts of the Rhododendron plant which indicates that the whole plant is a "mine of phytochemical," which is a non-nutritive plant chemical possessing protective or disease preventive properties [11]. The plant contains large amount of secondary metabolites such as alkaloids, flavonoids, glycosides, saponins, tannins, steroids and phlobatannins [4]. Secondary metabolites are critical component for plant survival and play a significant role in human health.

Table 2 Composition of Rhododendron flower and its juice

\begin{tabular}{|c|c|c|c|}
\hline Sr. no. & Attributes & Amount & References \\
\hline 1. & Moisture (\%) & 79.40 & {$[5,12]$} \\
\hline 2. & Ash (\%) & 2.30 & \\
\hline 3. & Crude fat (\%) & 1.52 & \\
\hline 4. & Crude fiber (\%) & 2.90 & \\
\hline 5. & Total nitrogen (\%) & 0.58 & \\
\hline 6. & Total proteins (\%) & 1.68 & \\
\hline 7. & Carbohydrates (\%) & 12.20 & \\
\hline 8. & Organic matter (\%) & 97.70 & \\
\hline 9. & Insoluble ash (\%) & 1.29 & \\
\hline 10. & Soluble ash (\%) & 1.15 & \\
\hline 11. & Ascorbic acid (mg/100 ml) & 11.5 & \\
\hline 12. & Total carotenoids ( $\mu \mathrm{g} / 100 \mathrm{ml})$ & 2685.0 & \\
\hline 13. & Flavanols (mg/100 ml) & 288.7 & \\
\hline 14. & Total flavonoids (mg/100 ml) & 1276.5 & \\
\hline 15. & Total anthocyanins (mg/L) & 154.8 & \\
\hline 16. & Total phenols (mg/100 ml) & 956.5 & \\
\hline 17. & $\begin{array}{l}\text { Total antioxidant capacity }\{\mathrm{mM} \\
\text { Trolox equivalent }(\mathrm{TE}) / \mathrm{L}\}\end{array}$ & 70.4 & \\
\hline \multicolumn{4}{|c|}{ Mineral content (ppm) } \\
\hline 18. & Manganese & 50.2 & {$[5]$} \\
\hline 19. & Iron & 405 & \\
\hline 20. & Zinc & 32 & \\
\hline 21. & Copper & 26 & \\
\hline 22. & Sodium & 385 & \\
\hline 23. & Chromium & 08 & \\
\hline 24. & Cobalt & $<0.5$ & \\
\hline 25. & Cadmium & $<1$ & \\
\hline 26. & Molybdenum & $<0.5$ & \\
\hline 27. & Nickel & 2 & \\
\hline 28. & Lead & 3 & \\
\hline 29. & Arsenic & $<0.5$ & \\
\hline
\end{tabular}




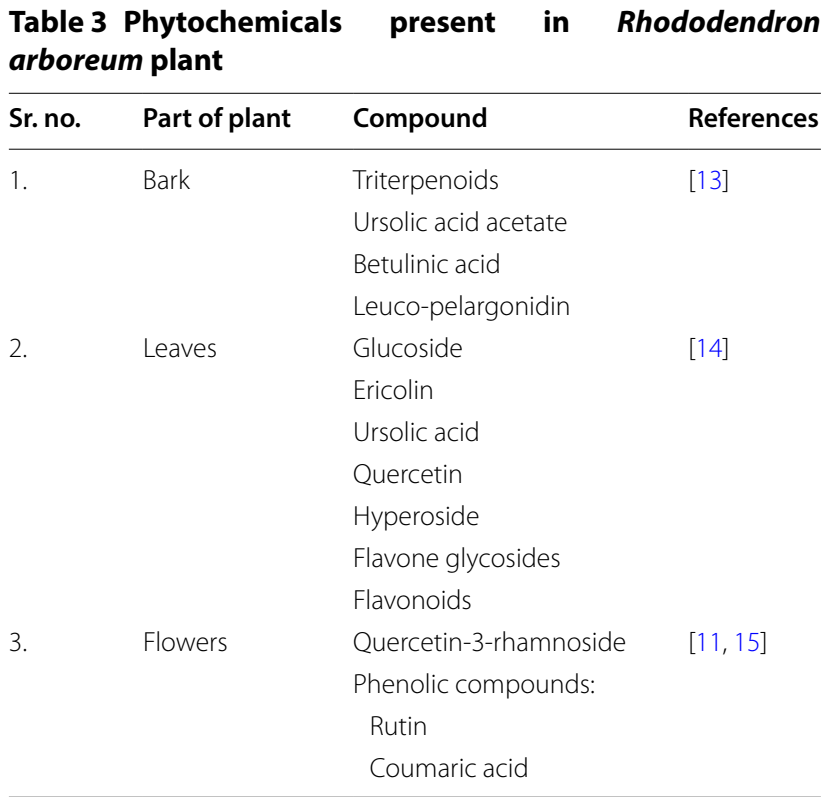

\section{Distribution of species of Rhododendron}

Worldwide, around 1200 species of Rhododendron have been estimated, among which China has the highest number of species, i.e., 571 species of total species in the world, of which 409 are endemic [16]. In India, there are about 80 species, 10 subspecies and 14 varieties. The existing records indicate that $98 \%$ of the Indian species are found in the Himalayan region, and $72 \%$ are found in Sikkim $[1,17]$

\section{Medicinal properties of Rhododendron plant}

Rhododendron is used traditionally in Far-West Nepal as a remedy for many diseases and is preferred for its diverse medicinal properties with low side-effect profile. Phenolic acids obtained from its leaves and twigs have been reported to have anti-HIV, anti-inflammatory, anti-nociceptive activities, and also its leaves and flowers are utilized for treating illness, headache, diabetes, rheumatism, etc. Some of the medicinal properties of its different parts along with their specific bioactive compounds and remarks are reviewed in Table 4.

\section{Utilization of Rhododendron flower}

Recently, the processors took interest in the utilization of the Rhododendron flower for the development of valuable food products; therefore, few products are available in the market. Few scientific researches have been done for the utilization of this flower, which could be due to its limited availability in limited places or the perishable nature of the flower. Some of the possible products which can be prepared from the Rhododendron flower are suggested here in this review which will open a new door for the researchers and processors to utilize this flower commercially for value addition.

Rhododendron flower juice besides being a refreshing drink is also believed to impart great medicinal value. Extraction of Rhododendron juice can be done by two methods, i.e., cold-pressing method and hot-pressing method. Traditionally, hot-pressing method of juice extraction is used by the processor (Fig. 1) [26], resulting into more yield, but at the same time the thermosensitive phytochemical properties get affected. Therefore, coldpressing method (Fig. 1) should be used by the processor to overcome their problem and to provide a wholesome product to the consumers. Rhododendron flowers could offer enormous opportunities for better marketing strategies for the sale of squash and other beverages. Other products such as preserve, appetizer, syrup, wine, vinegar, jam, jelly, instant juice mix, probiotic drinks, flavored milk and milk-based products are still not explored by the researchers and need further exploration in the future to bring Rhododendron plant into limelight for the Indian food industry [12]. If the right method of juice extraction is selected initially, then the final product will be nutritious. Attri et al. [20], Bhatt et al. [27] and Krishna et al. [12] made a valuable effort for the preparation and improvisation of the Rhododendron squash preparation method.

Beside production of juice and juice-based products, Rhododendron flower can also be used for the production of dried products (dried powder, ready-to-serve chutney mix, pickle, etc.). It is traditionally being used for making chutney by crushing the flowers and adding mint leaves, salt, anardana or tamarind for imparting a sour taste. However, these products have not been studied by the researchers still.

Rhododendron honey, also known as mad, wild or toxic honey, has been known since ancient times [28]. It is produced by honeybees which collect nectars from the flower of Rhododendron. It is reported to treat several disorders and is used traditionally as a medicine. It contains grayanotoxin and andromedotoxin as active ingredients. Grayanatoxin present in Rhododendron honey can cause severe vertigo, arterial hypotension and bradycardia if consumed in large amount [29]. However, some 


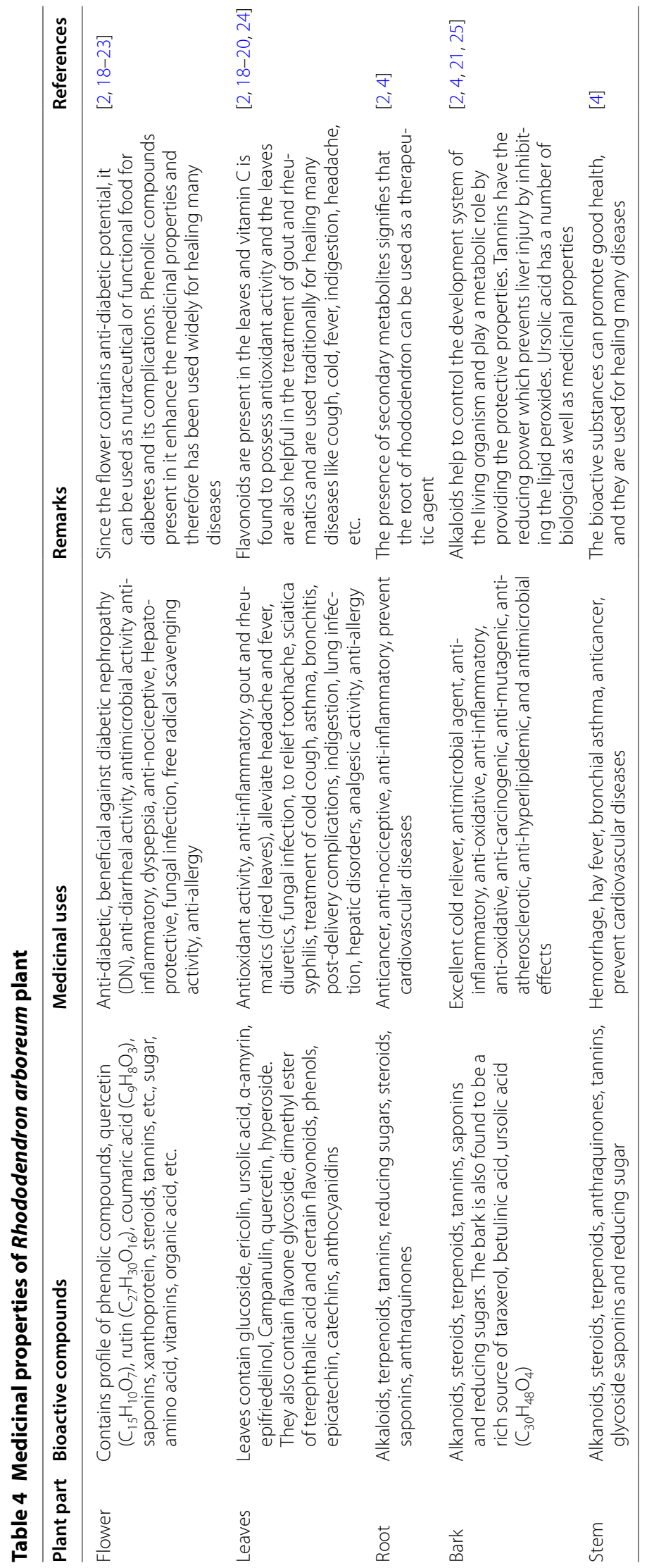


Hot pressing method

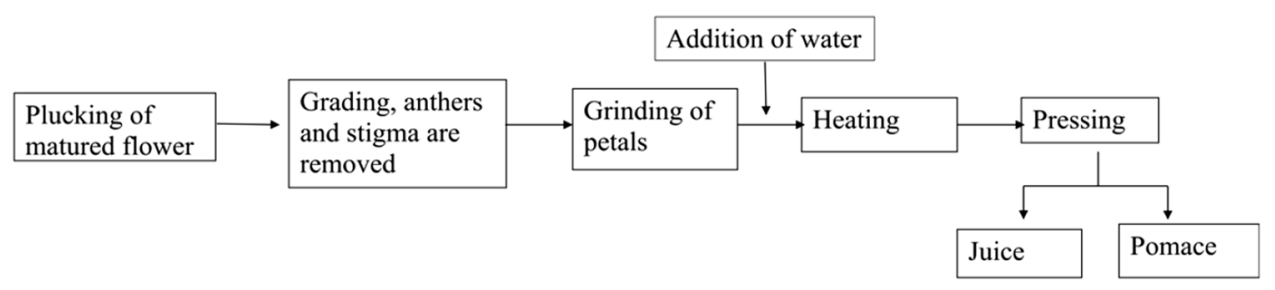

Cold pressing method

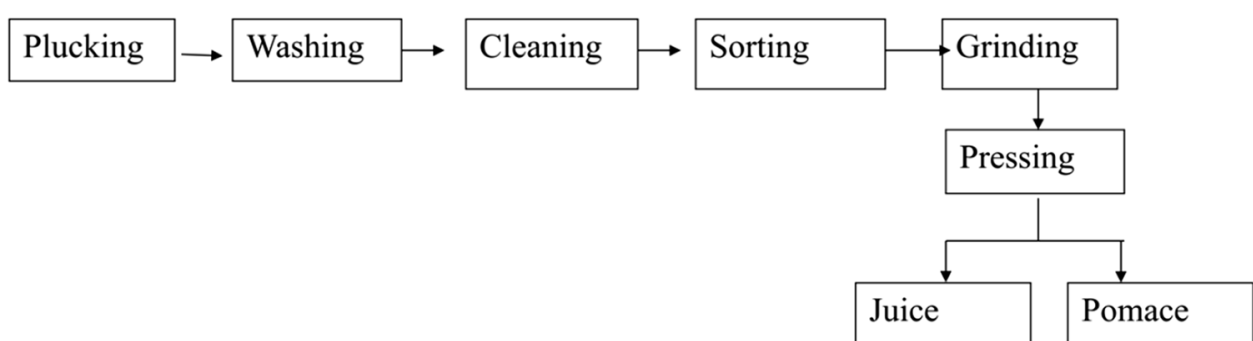

Fig. 1 Methods of Rhododendron flower juice extraction (hot and cold pressing)

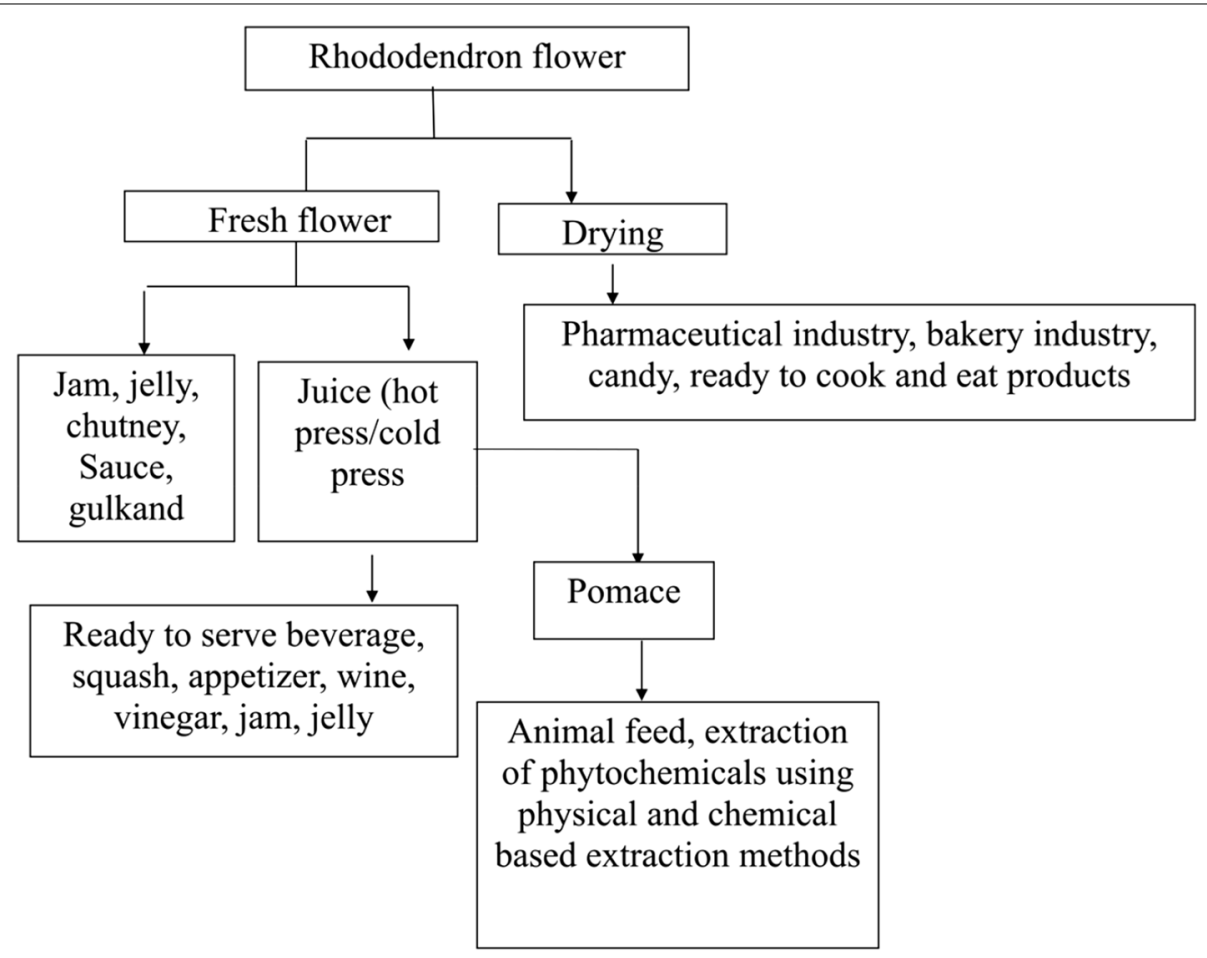

Fig. 2 Future prospective of Rhododendron flower

studies have reported that Rhododendron honey lowers blood glucose and lipid levels in the case of rats with diabetes mellitus. It has also been reported to impart anti-bacterial, antifungal, antioxidant and antimicrobial effects [30].

\section{Future prospective}

The commercial utilization of this flower for the development of various food and pharmaceutical products can help in the availability of this flower/flower-based product throughout the year. Therefore, this can help in the 
sustainable development of rural tribal populations with great possibilities of employment. The plant can also be used for the development of lifesaving drugs and could offer enormous opportunities for devising better marketing strategies. Development of sustainable use of this plant can hold a good prospective for local livelihood. More research is still required for value addition and creating awareness about its high nutritive and medicinal value among urban, rural and semi-urban consumers for solving the problem/prevalence of malnutrition on the one hand and economic development on the other [31]. Figure 2 depicts the brief future prospective of this flower for the development of wide range of food products which needs further exploration by the researchers for their existence in the food industry and market.

\section{Conclusions}

Rhododendron plants have number of health benefits along with antimicrobial activities and have full potency to be utilized in the food and beverage industry. This plant can be explored further by the researchers since it is still underutilized and is not properly preserved to make it available throughout the year. Authors have tried to review the medicinal properties as well as exploring different horizons for the utilization of Rhododendron flower and hoping that this review will attract the researchers to conduct research in this field for the value addition which may help in the enhancement of employment and economy for the upcoming generation.

\section{Abbreviations \\ WHO: World Health Organization; HIV: human immunodeficiency virus; mg/100 ml: milligrams per 100 ml; $\mu \mathrm{g} / 100 \mathrm{ml}$ : microgram per $100 \mathrm{ml}$; ppm: parts per million.}

\section{Authors' contributions}

VK is the sole author of the review article, whereas other authors have contributed equally for the literature collection, manuscript documentation and its revision. All authors read and approved the final manuscript.

\section{Acknowledgements}

The authors are thankful to Lovely Professional University for providing the necessary facilities, which were used for the preparation of manuscript.

\section{Competing interests}

The authors declare that they have no competing interests.

\section{Availability of data and materials}

Not applicable.

\section{Consent for publication}

The authors confirm that the content of the manuscript has not been published, or submitted for publication elsewhere.

Ethics approval and consent to participate Not applicable.

\section{Funding}

This research work has no funding.

\section{Publisher's Note}

Springer Nature remains neutral with regard to jurisdictional claims in published maps and institutional affiliations.

Received: 14 November 2018 Accepted: 3 January 2019

Published online: 14 January 2019

\section{References}

1. Tiwari ON, Chauhan UK. Rhododendron conservation in Sikkim Himalaya. Curr Sci India. 2006;90:532-41.

2. Srivastava P. Rhododendron Arboreum: an overview. J Appl Pharm Sci. 2012;02:158-62.

3. Prakash V, Rana S, Sagar A. Studies on antibacterial activity of leaf extracts of Rhododendron arboreum and Rhododendron campanulatum. Int J Curr Microbiol Appl Sci. 2016:5:315-22.

4. Nisar M, Ali S, Qaisar M, Gilani SN, Shah MR, Khan I, Ali G. Antifungal activity of bioactive constituents and bark extracts of Rhododendron arboreum. Bangladesh J Pharmacol. 2013;8:218-22.

5. Saklani S, Chandra S. Evaluation of in vitro antimicrobial activity, nutritional profile and phytochemical screening of Rhododendron arboreum. World J Pharm Sci. 2015:4:962-71.

6. Clinton BD, Vose JM. Effects of Rhododendron maximum L. on Acer rubrum L. seedling establishment. Castanea. 1996;61:38-45.

7. Wu FQ, Shen SK, Zhang XJ, Wang YH, Sun WB. Genetic diversity and population structure of an extremely endangered species: the world's largest Rhododendron. AoB Plants. 2015;7:plu082.

8. Shen SK, Wu FQ, Yang GS, Wang YH, Sun WB. Seed germination and seedling emergence in the extremely endangered species Rhododendron protistum var. giganteum-the world's largest Rhododendron. Flora Morphol Distrib Funct Ecol Plants. 2015;216:65-70.

9. Mao AA, Gogoi R. Rhododendrons of Manipur and Nagaland, India; 2012.

10. Soetan $\mathrm{KO}$, Olaiya $\mathrm{CO}$, Oyewole OE. The importance of mineral elements for humans, domestic animals and plants - a review. Afr J Food Sci. 2010;4:200-22.

11. Rangaswamy S, Sambamurthy K. Crystalline chemical components of the flowers of Rhododendron nilagiricum Zenk. Proc Indian Acad Sci A. 1960;51:322-7

12. Krishna H, Attri BL, Kumar A. Improvised Rhododendron squash: processing effects on antioxidant composition and organoleptic attributes. J Food Sci Technol Mys. 2014;51:3404-10.

13. Hariharan $V$, Rangaswami S. Chemical investigation of the bark of Rhododendron arboreum Sm. V. Curr Sci Arc. 1966:35:390-1.

14. Verma N, Singh AP, Amresh G, Sahu PK, Rao CV. Protective effect of ethyl acetate fraction of Rhododendron arboreum flowers against carbon tetrachloride-induced hepatotoxicity in experimental models. Indian J Pharmacol. 2011;43:291-5.

15. Swaroop A, Prakash Gupta A, Kumar Sinha A. Simultaneous determination of quercetin, rutin and coumaric acid in flowers of Rhododendron arboreum by HPTLC. Chromatographia. 2005;62(12):649-52.

16. Pradhan S. Antihyperglycemic effect of various medicinal plants of Sikkim Himalayas - a review. Int J Res Phytochem Pharmacol. 2011;1:124-30.

17. Sekar KC, Srivastava SK. Rhododendrons in Indian Himalayan region: diversity and conservation. Am J Plant Sci. 2010;1:131-7.

18. Bhattacharyya D. Rhododendron species and their uses with special reference to Himalayas: a review. Assam Univ J Sci Technol Biol Environ Sci. 2011;7:161-7.

19. ManiKumar P, Pardhu G, Ravinder S, Lakshmi V, Tejaswini K, Pradeep VB. Phytochemical screening, antimicrobial \& anti proliferative properties of Rhododendron ponticum on prostrate epithelial cancer cells. J Pharm Sci Res. 2011;3:1552-5.

20. Attri BL, Krishna $H$, Nazeer A, Kumar A. Effect of blending and storage on the physico-chemical, antioxidants and sensory quality of different squashes. Indian J Hortic. 2014;71:546-53. 
21. Gill S, Panthari P, Kharkwal H. Phytochemical investigation of high altitude medicinal plants Cinnamomum tamala (Buch-Ham) Nees and Eberm and Rhododendron arboreum Smith. Am J Phytomed Clin Ther. 2015;3:512-28.

22. Gautam V, Sharma A, Arora S, Bhardwaj R. Bioactive compounds in the different extracts of flowers of Rhododendron arboreum Sm. J Chem Pharm Res. 2016;8:439-44.

23. Zha HG, Milne RI, Zhou HX, Chen XY, Sun H. Identification and cloning of class II and III chitinases from alkaline floral nectar of Rhododendron irroratum, Ericaceae. Planta. 2016:244:805-18.

24. Kemertelidze EP, Shalashvili KG, Korsantiya BM, Nizharadze NO, Chipashvili NS. Therapeutic effect of phenolic compounds isolated from Rhododendron ungernii leaves. Pharm Chem J. 2007;41:10-3.

25. Lepcha L, Basistha BC, Pradhan S, Subba KB, Gurung R, Sharma NP. Understanding significant value of Rhododendron arboreum Smith Scarleti of Sikkim, India. Int J Eng Sci Innov Technol. 2014;3:554-9.

26. Hillsjester. Juice/squash of Rhododendron flowers; 2014. https://hillsjeste r.com/2013/04/29/juicesquash-of-Rhododendron-flowers/. Accessed 19 Sept 2017.
27. Bhatt M, Abrol GS, Kumar S, Nautiyal BP. Preparation and evaluation of functionally enriched squash from Rhododendron (Rhododendron arboreum Sm.) flowers. Int J Food Ferment Technol. 2017;7:191-6.

28. Rasgele PG, Kekecoglu M. Physico-chemical properties of Rhododendron honey produced in Turkey. Herba Polonica. 2013:59:88-97.

29. Jansen SA, Kleerekooper I, Hofman ZL, Kappen IF, Stary-Weinzinger A, van der Heyden MA. Grayanotoxin poisoning:'mad honey disease' and beyond. Cardiovasc Toxicol. 2012;12:208-15.

30. Silici S, Sagdic O, Ekici L. Total phenolic content, antiradical, antioxidant and antimicrobial activities of Rhododendron honeys. Food Chem. 2010;121:238-43.

31. Kumar P, Shaunak I, Thakur AK, Srivastava DK. Health promising medicinal molecules in vegetable crops. J Genet Genomes. 2017;1:102.
Ready to submit your research? Choose BMC and benefit from:

- fast, convenient online submission

- thorough peer review by experienced researchers in your field

- rapid publication on acceptance

- support for research data, including large and complex data types

- gold Open Access which fosters wider collaboration and increased citations

- maximum visibility for your research: over $100 \mathrm{M}$ website views per year

At BMC, research is always in progress.

Learn more biomedcentral.com/submissions 